\title{
Systemic leadership for socio-political stewardship
}

\author{
R.G. Taylor* \\ Leadership Centre, University of KwaZulu-Natal, \\ Republic of South Africa \\ taylorr@ukzn.ac.za \\ S.A. Lynham \\ College of Applied Human Sciences, Colorado State University, \\ Fort Collins, Colorado, USA \\ salynham@aol.com
}

\begin{abstract}
The role of business leadership in defining, and enacting, societal values and providing consolidating influences relative to change processes is increasingly being recognised. This role is best defined as one of "stewardship", embracing the securing of social, political and economic futures. For business leadership, the increased recognition of the ability for it to influence the trajectory of change, and indeed the expectation that it should do so, brings with it a need to revisit contemporary understandings of leadership and how that leadership is best engaged so as to facilitate desirable outcomes.
\end{abstract}

This paper adopts a critical position relative to the conventional "leader, follower, situation" configurations of leadership thinking. Drawing on theory located within the knowledge domain of systems thinking and network theory, leadership is redefined at a conceptual level, hence to understand the processes by which it is enacted and experienced and how, therefore, it can be better practiced in the broader socio-political domain. Leadership is considered as an emergent phenomenon that creates definitional distinction between actors and process so as to provide new insights.

The paper includes outcomes of a research study that was conducted amongst business leadership in South Africa. The study covered the period 1984-1994, a period of considerable large scale change in South Africa, during which time lessons about leadership were learned. These lessons validate the significant potential that business leadership has for monitoring and influence beyond the immediate concerns of business itself. The assumption of the role of "steward" typified much of what emerged from that engagement, but also gave opportunity for reflections about revised theoretical frameworks for leadership practice in the $21^{\text {st }}$ Century. The case material arising from this research also provides demonstration of the appropriateness of the theoretical propositions that form the conceptual basis for the paper.

*To whom all correspondence should be addressed.

\section{Introduction}

The role of business in society, and the diverse interpretations of that role, has generated much debate. Some of that debate is located in philosophical differences. Liberals and Marxists, for example, differed strongly on the role that business ought to have played during the apartheid era in South Africa. The former advocated a process of engagement and pressure so as to erode apartheid, the latter clung to the belief that business ultimately was only driven by self-interest and was persuaded to shift only when the "demise of apartheid became unstoppable" (Lipton, 2007:292-301). These differing perspectives defined - and continue to define - the divergent views regarding that which was expected of business as a social and political actor at that time.

Other differences are more generally located in attempts to define more general expectations about the role of business in society. The expression of these expectations is intended to apply pressure on business in order that it might embrace an even greater societal role that it already does. Recent work asserts that the typical business response has been one of unjustified, and often unqualified, contrition and apologetic action (Bernstein, 2010). Business, Bernstein argues, has mostly survived through time by its willingness to recognise societal needs and values and to incorporate these into its practices. Yet there are unfulfilled (and often vociferously expressed) expectations that have served to redefine the manner in which business is structured and how leadership is practiced within (and between) those structures. It is in these areas of role redefinition, rates of change and consequent capacity to deliver effective leadership in a milieu of escalating crises and pressure that organisations find they are engaging in less familiar pursuits. 
Attempts to define (and disagreements about) the role of business in society are not new. Attempts to define (and refine) the value systems that underpin the functioning of communities and their practices, including those of business, are also not new. Many have lamented a system of values that seemingly promotes the interests of a few over those of the many. For example, Churchman (1968) outlines the perplexing phenomenon of so much deprivation in a global context of plenty. More recently (and more specifically in the context of this paper) Laszlo (2006) speaks of a world in a crisis of (in his opinion) misplaced values that business has considerable capacity to influence and change.

Former South African President Mbeki, too, in the Nelson Mandela Memorial Lecture (2006) reminded his audience of the need to rekindle that sense of "soul" that defines human beings as socially-responsible and community-sensitive actors and not only players on an economic stage.

For business, particularly South African business in the recent past (and even at the present time), the preceding brief comments about the role of business and values are entirely relevant. They also provide insight into part of the organisational context from which some elements of South African business, in the period 1984-1994, "crashed" the established boundaries of business practice and defined (at least for the time being) a space from which to facilitate political change. The conventional values context for business was - perhaps, for some, still mostly is substantially defined by the early ideas of Adam Smith and later by Friedman's (1970) concepts of "social responsibility". In essence (and perhaps simplistically) this means that business should only act with the purpose of increasing shareholder value. Socially responsible actions can only be given credence when they are subservient to that purpose. Within the context of such a value system, any overtly socio-political actions of business could feasibly meet with suspicion and opposition from within business itself. So the understanding by organized business regarding what is, and what is not, the "business of business" provides part of the context for involvement. A further aspect relates to the sanction of society at large for the actions of business in engaging change (see e.g. Cohen \& Ben-Porat, 2008 whose discussion of the Israeli-Palestinian conflict speaks to this issue).

Whatever the perceived origins and/or motivations (and whether justified or not) socio-cultural and environmental accountability has become the business of business. Csikszentmihalyi (2003:6-9) has placed this within an historical context in claiming that the nobility and clergy have made way for the scientist and business as the entrusted agents of change and improvement and, indeed, the custodians of moral rectitude. Regrettably, as with the nobility and the clergy before, neither science nor business has always honoured that trust.

Science and business are, however, significant areas of action for global human benefit not only through technological innovation but also through the development of systems of governance and practices that preference global "stewardship" above potentially exploitive economic gain. For business, the embrace of "stewardship" implies a further evolution of its role and place within the systemic framework of broader society. Structures, norms and practices of business itself in a growing context of sociocultural and environmental awareness requires acknowledgement of the need for a paradigm of leadership that is increasingly founded on understandings of natural evolutionary processes rather than by the all-too-familiar mechanistic, control-oriented prescription that typifies the experiences of many. Dervitsiotis (2005:941) espouses the need for a "new language" (see Figure 1) as a vehicle for the enablement of new thinking about the practice of business and its role in society so as to provide the means for the liberation of creative energy in the resolution of the larger problems that comprise the global "mess". This language characterises a shift from that which is associated with the assumptions of predictability and the certainty, to that which focuses on assumptions of movement and uncertainty. As such it facilitates a dialogue about the meaning of stewardship and indeed the nature of leadership itself in a complex and changing world.

There is probably little dispute that business would seek to create for itself an environment in which survival is facilitated and it would therefore act towards that end. The concept of "stewardship" that embodies a quest to secure sustainable futures would therefore implicitly be part of business strategic thinking.

No claim is being made here to prescribe ultimate solutions for that which is unfamiliar. Indeed, to presume to do so would be to also contradict the basic argument of the paper itself -i.e. that the world is an indeterminate one, most real world problems are complex, and that our actions (and inactions) carry us to new and often unexpected places. At best, directions and possibilities for improvement as part of an evolutionary journey can merely be presented, premised on the idea that meaningful change is best considered as a learning journey where the intended destination may be reached (but that cannot be guaranteed), nor can the means (or exact route) of travel necessarily be assured.

Leadership in the service of stewardship comprises the substance of this paper. In turn, the relevance of systems thinking as an informing framework for the practice of leadership in circumstances of societal change is explored. Reynolds (2008) provides a useful construct that comprises a triadic critical systems framework to be used as a basis for the enactment of programmes of corporate social responsibility (CSR). This framework holds relevance for the present purpose. Firstly, systems thinking as a "framework for practice"; secondly, systems thinking as a "framework for understanding"; thirdly, systems thinking as a "framework for responsibility". Taken together, these three frameworks are conceived to provide insight into the systemic basis for leadership action to influence sociopolitical change. 


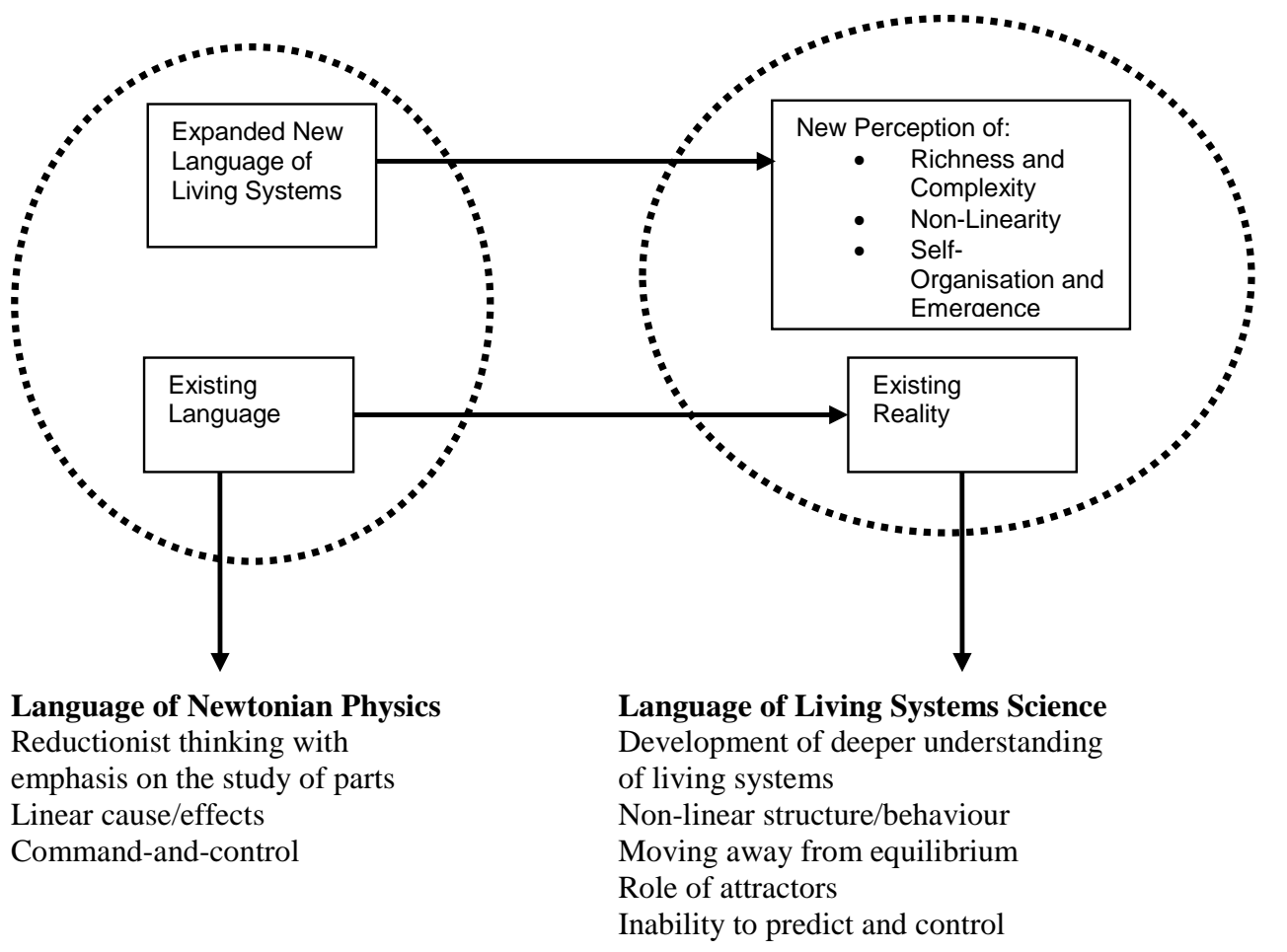

Figure 1: The impact of new language introduced by a living systems approach (Adapted from Dervitsiotis, 2005:941)

\section{Theoretical frameworks}

Two bodies of theory inform this discussion. The first is systems and systems thinking which provides a framework for understanding and responsible action; the second is leadership as a systemic phenomenon which provides a framework for practice. Both locate within an epistemological framework that seeks to learn about and manage complexity in situations where analysis alone fails. What, therefore, defines complexity?

\section{About complexity and ways of knowing.}

The universe has always been known to be both complex as well as mysterious. Throughout history, people have sought to unravel the complexity in order to understand the mystery. This pursuit has kept the scientific community active and has enabled great advances in knowledge and application, particularly in the furtherance of human technological competence. The familiar systematic analytical processes of science have indeed delivered much that is positive and empowering. The same analytical processes have, perhaps ironically, also led to a growing understanding of how limited those processes can be in relation to problems that analysis alone cannot resolve. Such problem situations have been referred to as "messes" (Churchman, 1968). This term is not only descriptive of many real world problems but has resonance with much of the everyday experiences of ordinary citizens. In essence a "mess" refers to those intractable problems that seemingly defy solution and, in fact, tend to intensify in their negative consequences over time. Technological prowess, fuelled by commercial interests, has simply not solved the world's pressing socio-cultural and environmental problems. In brief, our technological mastery and achievements have not been emulated in the socio-cultural or environmental realms. Indeed, the very technologies and economic practices that have emancipated and empowered some are the same that (inadvertently perhaps) may have impoverished many more others.

Previous work has explored the development of organisational thinking in relation to the evolving socioeconomic context in which that thinking was developed (Taylor, 2004). Assumptions of relative predictability have had to make way for those of relative unpredictability; assumptions about the nature of control and capacity to exercise control have had to be reconsidered; assumptions about unity of organisational purpose have had to make way for the understanding of diverse perspectives and individual consciousness; and assumptions about relative individual and organisational isolation from a broader socio-economic environment have had to make way for organisational integration into the broader socio-economic environment. Inherent in each of these assumption shifts is that which also defines complexity and the complex. They place consequent emphasis on a leadership that can increasingly comprehend the dynamic interplay between individual, organisation and society at large. The "mess" is thus characterised by the descriptors usually associated with systems thinking and complexity theory, namely the unpredictable, unintended consequences, positive and negative feedback loops, nonlinearity and emergence, to name a few. In brief, responses to change cannot be determined by analysis alone. Neither can responses be enacted by decree or reduced to codes, rules, policies and procedures, however well-intended those may be.

Complex systems are further characterised through three related dimensions of complexity that can be found 
singularly or in combination in any problem situation (Kahane, 2004:1-2). The first is dynamic complexity that defines the connection time between cause and effect. For example, how close is the coupling between events, their detection and the effect of actions arising from those events? The second is generative complexity that defines the degree of predictability that attends any given action. The third is social complexity that identifies differing value positions between individuals and groups as being relevant to the manner in which organisational decisions are made and action occurs. Social complexity, as defined here, is embedded in the self-reflective and perceptual capacity of people both inside and outside the organisation. In brief, systems are defined by the way in which they are perceived by participants in them and observers of them, thus leading to multiple subjective interpretations of the world itself. Objective reality is only a partial, limited reality. Subjective reality - "ways of seeing that are also ways of not seeing"enables insight and interpretation that is driven by what is actually perceived and how it is interpreted and understood by the observer.

Organisational decisions that include a much broader system of concern that also embraces socio-cultural and environmental attributes as aspects of central, rather than peripheral, points of concern, intensifies the challenge. At a practical level (for example), the familiar processes of quality management (or performance management) have new meaning when they become seen in a context of the social, economic and environmental impacts that transcend the concern of supplier for supplied (or the relationship between the employer and employee).

Jackson (2009:S25), referring to Boulding's (1956) hierarchy of complexity, locates socio-cultural issues at level seven (and above) of Boulding's nine level hierarchy (see Table 1). Although generally accepted as a useful way of thinking about complexity, Boulding's hierarchy has been refined so as to include more precise definition of the real nature of complexity in different types of systems. Mingers' (1997: 306-309) explanation of the need to focus on system definitions that foreground "different types of relationship" in systems is instructive but does not fundamentally change the argument of this paper. In essence, the hierarchy (however defined) identifies how poorly developed our capacity is to deal with problems that are located in the socio-cultural arena (at the upper end of the hierarchy).

The usefulness of the hierarchy has more than one dimension. The first dimension is that associated with a move towards more holistic and "connected" approaches to problem solving (as espoused by system thinking). The second, and related dimension, is about the definition of leadership itself that creates the context within which new insights and understandings may emerge. It is evident that the upper levels of Boulding's hierarchy are essentially about more widely-defined and therefore less immediately accessible systems and complex, unpredictable relationships. It is this inaccessibility and the "fluid" nature of such systems that reinforces the need to develop specific forms of leadership that recognise the relationship between systems thinking (on the one hand) and leadership (on the other). This upper end is also the area in which business is being increasingly challenged to embrace "stewardship" and enact its leadership towards the realisation of that role.

\section{Systems and systems thinking}

Systems and 'systems thinking' have attracted the attention of many. General Systems Theory directed thought towards the goal of a theory of explanation based upon holism (Von Bertallanfy, 1968). Arising from this, a great deal of intellectual and practical energy has been engaged in the refinement of systems ideas and practices. This energy has led to the emergence of many ideas about the nature of systems and ways of coming to understand them, and to work effectively within them, i.e. providing a "framework for understanding". Elements of this development, namely the recognition of 'hierarchy and emergence' and 'communications and control' as key characteristics of systems, are important and will therefore be elaborated upon here.

\section{Table 1: A summary of Boulding's (1956) hierarchy of complexity}

1. At level 1 are structures and frameworks which exhibit static behaviour and are studied by verbal or pictorial description in any discipline; an example being crystal structures

2. At level 2 are clockworks which exhibit predetermined motion and are studied by classical natural science; an example being the solar system

3. At level 3 are control mechanisms which exhibit closed-loop control and are studies by cybernetics; an example being a thermostat

4. At level 4 are open systems which exhibit structural self-maintenance and are studies by theories of metabolism; an example being a biological cell

5. At level 5 are lower organisms which have functional parts, exhibit blue-print growth and reproduction, and are studied by botany; an example being a plant

6. At level 6 are animals which have a brain to guide behaviour, are capable of learning, and are studies by biology; an example being an animal

7. At level 7 are people who also possess self-consciousness, know that they know, employ symbolic language, and are studied by biology and psychology; an example being a human being

8. At level 8 are socio-cultural systems which are typified by the existence of roles, communications and the transmission of values, and are studied by history, sociology, anthropology and behavioural science; an example being a nation

9. At level 9 are transcendental systems, the home of "inescapable unknowables", and which no scientific discipline can capture; an example being the idea of God 
Systems are, in the first instance and by definition, about the fulfilment of a purpose. They exist, according to in order to address or achieve some or other outcome (Churchman, 1968). In the language of systems, such an outcome would be seen to be the 'emergent' property of that system. Inevitably, the outcome could be positive or negative or a range of possibilities in between. The pertinent issue is that any system receives inputs, transforms these and delivers outputs, and it may do this well or badly. This is depicted diagrammatically in Figure 2. For leadership, this would all be familiar. That which is less familiar is the manner in which a systems approach would seek to identify and correct system malfunction, so as to bring about improved, sustained system performance.

Figure 2 is instructive in enabling leaders to conceptualise social change as being fundamentally a function of interaction and counteraction amongst the institutions and individuals who comprise the system itself, others in the broader systemic space and, ultimately, the environment beyond the boundaries of the system itself. In this sense, systems thinking represents a "framework for practice and understanding" that defines any system to be an emergent product of its component parts which exist in interactive relationship with each other. The perceiving, conceptual capacity and behaviour of the individual elements of the system have a primary role to play in the business of change and in determining the direction, pace and strength of that change.

In complex systems, to assume that the way in which the variables interact, or how any changes would influence system performance, can be completely knowable is open to question. It is also not typically possible to establish how change on the part of individual elements of the system would be perceived by others either in the system or in the environment of the system and therefore how change would affect emergent system outputs.

It also cannot be assumed that all stakeholder groups would understand or perceive any system in the same way; nor can it be supposed that shifts in stakeholder perceptions and focus will not occur during engagement. Flood and Jackson (1991) (drawing on the work of Morgan, 1986) explain how the same system can simultaneously be defined as a system of technical interaction; a system of political interests and power; a system in organic interaction with its environment, amongst others, according to how it is perceived. It is these diverse views of systems, system boundaries and understandings of system purpose that typically precipitate conflict. Clearly, the ability to accommodate and work with diverse understandings and system definitions is critical. An ongoing challenge for leadership therefore is to observe, learn from, and correct the unintended effects that may arise from the reciprocal relationship between the system and its environment. This is done through a capacity to share interpretations by dialogue and exchange, being accepting of feedback and changes in role, and openness to learning. In brief, it is about "being systemic" or engaging a framework for mutual understanding through dialogue that also creates a context for ethical action (i.e. "a framework for responsibility").

Five dimensions have been identified to form the basis for real dialogue (Cayer, 2005). While cautioning that any analytical approach to the consideration of the act of dialogue might serve to destroy the nature of the "flow" that typifies real dialogue, Cayer's formulation is useful. The five dimensions are paraphrased to be:

- Conversation, meaning to talk together without an agenda but with empathy and respect; to share experience and be understanding.

- Inquiry, meaning to be willing to "unlearn" and to explore beliefs and feelings, to be reflexive.

- Creating shared meaning, meaning suspension of judgment and accepting the risk of being transformed, allowing diversity of viewpoint.

- $\quad$ Participatory process, meaning absence of hierarchy and a new form of consciousness, a perception of interconnectedness;

- Collective meditation, meaning acceptance of reality of the present moment without attempting to change people, attending to the thought processes individually and collectively.

Kahane (2004:x) adds to this the point that, in a situation of real dialogue, command and control do not work. It is rather necessary to be adaptive and receptive to ideas but also be prepared to move beyond the boundaries of understood practice or comfort zones and to open up to complexity.

Managing "emergent" potential is therefore partly about managing the variable mix, in terms of points of engagement and/or perceptions. It is also about "letting go" and feeling comfortable with the uncontrolled, or at least that which is controlled only within the broad framework of the vision. In sum, it is emergence that lends specific characteristics to systems and renders them distinctively innovative (or otherwise) in a changing, uncontrollable world. 


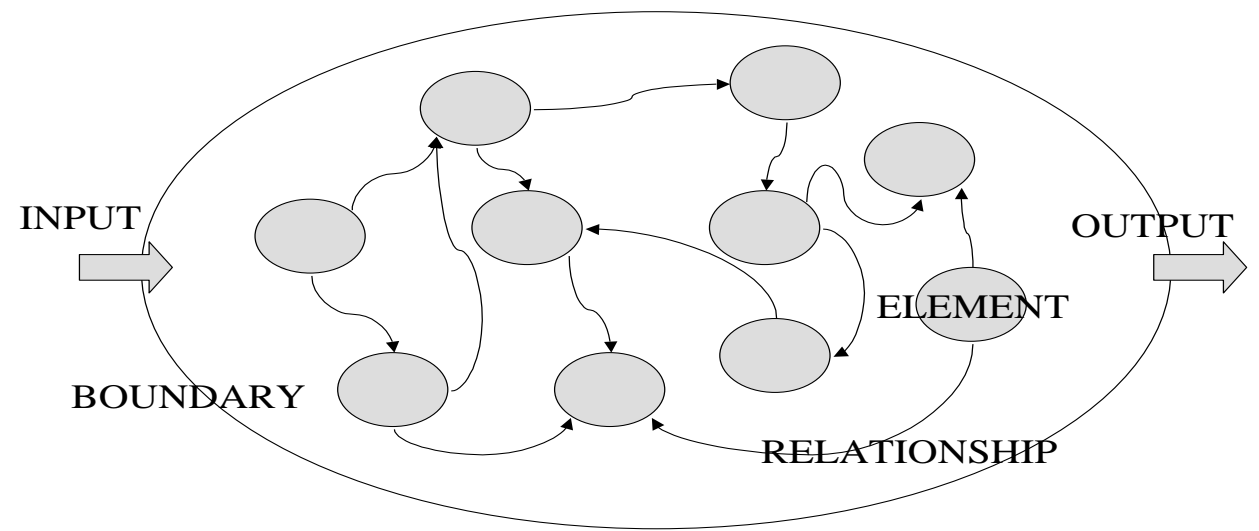

Figure 2: Schematic depiction of a system, indicating complex feedback and relational loops (Source: Flood and Jackson, 1991:6).

But this, too, is not new. Biological organisms and entire eco-systems have been changing and adapting to environmental stimuli for thousands of years as part of a seemingly unguided, uncontrolled process. This is called evolution. It is also the means towards survival. Systems can indeed self-organise. This, too, is not new. Lewin (1992) for example, reflects on the inherent, though seemingly mystical capacity of complex systems to gravitate towards certain states defined by the existence of certain 'strange attractors'. Order and orderliness, attributed to such strange attractors, is that which serves to bound the system and to define the number of possible states that it may adopt. Indeed, such attractors give to complex systems that characteristic that removes them from the world of the chaotic and positions them as ordered, self-regulating systems. The essence of self-organisation is a process of bounded pattern formation. While the formation of patterns, their detection and their modification is easier in the case of natural systems, social systems (even though more complex and less predictable) tend to be patterned. The patterns are detectable and can be modified by strategic interventions that facilitate new forms of emergence arising from the introduction of new variable elements or different attractors.

In complex systems, such as those located at the upper end of Boulding's hierarchy (see Table 1), the assumption that the way in which the variables interact can be completely "knowable" is probably fallacious. It is indeed possible to make an informed determination of what the relevant variables might be, and to make assumptions about the possible interaction of those variables, but for the most part, there are no deterministic tools or schema whereby we can predict the evolution of complex systems with complete certainty. The unintended consequences of isolated, disconnected actions in pursuit of social, economic and political agendas can lead to the emergent "mess" of profound disadvantage and for many, juxtaposed against the advantages of the relatively few.

\section{Leadership as systemic phenomenon}

The strategic challenge for leadership is to maintain multiple points of stability within an environmental context of change and flux, hence preserving a semblance of stability and direction in a "chaotic" world, where that which is "unknowable" is the norm and therefore the challenge to contemporary leadership. Effective leadership, too, would need to embody such a capacity.

Burns (1978:2) declares that "leadership is one of the most observed and least understood phenomena on earth". In spite of this still being generally true, Van Vugt (2006), in his review of literature pertaining to the phenomenon of leadership, does conclude that considerable development has occurred towards developing a more complete understanding of leadership. Whilst this is indeed so, the academic discipline fields remain dispersed and fragmented. Van Vugt identifies the potential for research synergy between the evolutionary sciences, on the one hand, and psychology, on the other. Others have similarly concluded that leadership behaviour is essentially interplay between environmental cues and psychological mechanisms (Pierce \& White, 1999). In their consideration of "adonic" and "hedonic" styles of primate behaviour, the point is also made that the observation of the adaptive behaviours that occur within the natural world hold parallel potential process lessons for the organisational world.

It is however true that, whilst there is scope for development of novel research linkages, a large body of knowledge about "leaders" and "leadership" has been produced. Much has been written and explored about "good" and "bad" leaders as a platform for exploration of "leadership". Similar work has connected "leaders" to "followers" to "situation" in an attempt to organise these three elements for purposes of establishing potential rules for leader behaviours, so as to guide appropriate leadership practices (Fiedler, 1967). Most contemporary formal generic concepts of leadership embody the conceptual trilogy of "leader", "follower" and "situation". Included amongst these are transactional 
leadership, transformational leadership and servant leadership. Although undoubtedly useful, it is perhaps in these attempts to fragment and analyse the components (or "parts") of leadership that the truth is being obscured. Similarly, the tendency to conflate the idea of "leader" with "leadership" confuses a process ("leadership") with an actor ("leader"), whose designation may have more to do with hierarchical position than capacity to understand or practice competent leadership or appreciate the significance of the context within which leadership occurs. Much work, for example, has been done throughout history - both ancient and modern - to document the behaviour of leader figures and to extrapolate generic lessons about leadership. While these are useful studies in the relationship between behaviours and outcomes, there is similarity in such an approach to the assumption that case studies provide generic learning, rather than merely an interesting set of lessons that may not work in a different context.

Leadership writing (Senge, Kleiner, Roberts, Ross, Roth \& Smith, 1999; Boyatzis \& McKee, 2005) has indeed made considerable progress in shifting understandings of leadership to be mostly a phenomenon arising from mutual trust, consciousness and self awareness. Significantly, Wood (2005) explains leadership in terms of the processual nature of the "real" - an inter-relatedness that holds and sustains processes best defines the world that, according to his reasoning, is more about "becoming" (or emergence) than it is about "being" (or existence). In this view, therefore, leaders, followers, and situation, are simply convenient constructs that represent the surface elements of an underlying process that relies on relationships, collective sense making and continuous flow to form the real basis for understanding leadership practice. Hence there is a view of leadership that defines it as perceptual as well as creative; a dissipative system that is in constant dynamic renewal and transformation.

Csikszentmihalyi (2003) also defines "good business" to be about "flow" and "making of meaning" in a context of continuous change, hence to emphasise the processes of movement as being that which defines leadership. Leadership cannot therefore be easily separated from the institutions, economic and social systems that are vehicles for action and change in the real world. Nor can it be conveniently isolated from the total sweep of history that develops from the past but also needs to contemplate the future. Artistic composition, for example, derives its meaning from the whole, including the social context and historic period in which it was produced.

Interpretation, composition and communication are central to the practice and appreciation of art. Leadership has been defined as 'an art', thus providing valuable insight into the true nature of leadership (De Pree, 1989). Others have directed attention to the manner in which emotion and spirit influence states of awareness, and hence play a subjective role in insight and appreciation, (Zohar \& Marshall, 1994). Appreciation of art does indeed involve interplay of the senses including the objective and the subjective as well as the context within which experience occurs. Using ideas deriving from complexity theory, Kurtz and Snowden (2003), write about patterns of relationships, pattern detection, and pattern formation and modification as being key elements in developing organisational understanding. These ideas, and others like them, define a competence that is about synthesis rather than scientific analysis; about art rather than science. They also provide signposts as to the nature of leadership in complex environments.

Wilson (1998) has contrasted the nature of science with the nature of art, defining both as attempts to deal with complex phenomena, where science delights in the disclosure of the detail that comprises the whole and art, by way of contrast, revels in the diverse interpretations of complex wholes, and how the parts resonate and harmonise with one another. Wilson goes further, stating how difficult it is to accurately and definitively comprehend complexity because complexity is not easily bounded, nor are human beings naturally encoded to cope with complex phenomena. Yet interpretation of complexity and composition and communication of response is the substance of the art of leadership. Interpretation implies the existence of diverse perspectives, as indeed does composition. The ability to accept and work with diversity and to move away from the idea that there is only one truth, (or "one best way" in the language of scientific management) further emphasises the nature of leadership as art rather than science but does not detract from the need for science or importance of the analytical methods of science.

In sum, therefore, leadership is hypothesised to be a form of "emergent" art, intending to interpret real world complexity in diverse ways and to use such interpretations to compose and communicate in order to facilitate sustainable progress.

\section{Systems and leadership}

The generic model of a system (Figure 2) is, in essence, also a generic model for understanding leadership. This may not have been immediately obvious. Systems have defined boundaries and exist to fulfil defined purposes; systems receive inputs, interpret and transform these through the interaction of the system elements; systems deliver outputs and are receptive to feedback that in turn redefines the perceptions of system participants and hence system behaviours. Systems are interactive, dynamic, evolving processes. So is leadership. "Leaders" alone do not constitute leadership. (This thought may serve to disappoint some and that is regrettable; reality does sometimes serve to disappoint). Leadership is an emergent process that certainly does involve leaders and followers and situation but it is conceptually and essentially concerned with whole systems that cannot be defined or understood through an exclusive examination of the parts that comprise the system. Leadership therefore is mostly a systemic phenomenon that evolves as a dialogue between people and groups within institutions, between institutions and between society and institutions, and indeed within and between the global communities. Such a perspective on leadership does suppose the existence of a context that is appropriate for its enactment. What then is the type of context that enables leadership to assume the attributes associated with systems and systems thinking; and that provides the frameworks for understanding, practice and responsibility that Reynolds 
(2008) identifies as the characteristic hallmarks of systems thinking in action?

An attempt to answer this question lies in the work of Morgan (1986) who identifies eight metaphorical views of organisations. All of these views represent potentially legitimate "ways of seeing" the systems that comprise organisations. As such the metaphors offer ways of comprehending the diversity of organisational and individual behaviours. Discussion of the range of metaphors is not the purpose of this paper. It is sufficient perhaps to say that the metaphors that correspond to the lower levels of Boulding's hierarchy (i.e. organisations as machines, organisms, or brains, or even instruments of domination) are unlikely to provide adequate explanation of the types of capacity that contemporary organisational leadership requires. For this reason, Alvesson and Deetz (1996) propose the addition of a further metaphor - "organisations as carnivals". While this may appear to add a dimension of the flippant and foolish to the business of business, the basis for this proposition against the backdrop of contemporary globalising reality is sound. Our world is indeed "subversive of order" as Jackson suggests and our attempts to understand it as ordered and controllable are known to be flawed. If this were not so, our global reality would not fit the image of Churchman's "mess". So the carnival that recognises the need to embrace new and diverse perspectives, enables inclusion, creativity and innovation, encourages emotional engagement and spiritual renewal presents an image of the type of organisational milieu and paradigm for leadership for effective and responsible/ethical stewardship needed in the contemporary era. The notion of a carnival provides leadership with images of change, turbulence and response that are not pre-ordained or enacted according to any script.

\section{Business leadership for systemic change}

Almost always, the creative dedicated minority has made the world better.

Martin Luther King

The leadership provided by business in the period from 1984-1994 in South Africa provides a useful illustration of the core ideas contained in this paper. Although business had the predisposition to be remote from political engagement for broader social purpose, South Africa (especially after 1976) was moving to a point where the ability of business to function as business was becoming untenable.

The catalytic riots in Soweto on 16 June 1976 created local instability and attracted unfavourable international attention. Government response locally, regionally and internationally was one of limited political reform and regional antiinsurgency agreements coupled with the ruthless suppression of internal political dissent. The threat of communism undoubtedly loomed large. The known transactions, military and otherwise, between the African National Congress (ANC)- at the time a liberation movement- and a range of communist regimes did little to allay fears. The imposition of an ever-widening range of economic and cultural sanctions and growing international isolation created an extremely unhealthy environment for business.

It was from this complex and tense setting that a small group of business leaders emerged in an attempt to contribute to meaningful change. The process by which they acted is the focus of this paper. The proposition of this paper therefore is that the process by which business leaders engaged amongst itself and with others during the period 1984-1994 illustrates the claim "...that leadership itself is a system, meaning it consists of interacting, interdependent inputs, processes, outputs, feedback and boundaries" (Lynham, 2000:49) and that this informed their understanding, practice and sense of responsible stewardship. In addition, it also provided lessons about leadership that departed significantly from the deeply held understandings of business about how responsible leadership should be practiced.

\section{Research methodology}

Using an emergent study design conducted from a constructivist perspective (Lincoln \& Guba, 1985 \& 2005; Lincoln, Lynham, \& Guba, 2011) and descriptive phenomenological methodology (Van Manen, 1990), the lived experience of business leadership of a particular group of SA business leaders during the decade preceeding the end of apartheid was studied. The directing research question for this study was: "What was the lived experience of leadership of this particular group of business leaders during the mid1980s to mid-1990s?" In keeping with the inquiry perspective, methodology and subsequent design, participants - business leaders instrumental in the formation and leadership of the Consultative Business Movement (CBM) during the targeted decade-were identified through purposive, snowball sampling (Lincoln \& Guba, 1985) and interviewed. The CBM, the vision of a handful of influential SA business leaders, was conceptualized in the early 1980s, formalized towards the end of the decade, and disbanded in the 1990s (Lynham et al., 2006). The purpose of the CBM was to challenge SA business people to "...use their not inconsequential power to advance the society towards nonracial democracy" (Nel, as cited in Terreblanche, 2002:79). As such, it played a not inconsequential role, along with many other organisations and groups, in helping to align the economic voice at the time behind ending apartheid (WEF, 2004). The participant data, informed by a total of 19 participants, were stratified into four groups, each of which uniquely informed the business leadership experience under study. Nine participants informed the tier one group: those business leaders who were the pioneers of the CBM and thus instrumental in the visioning and formation of the organisation, and what it was to become. Three participants (one repeated from tier one) informed the tier two group: those who were involved in the organisation after it had been formalized and later extended to include approximately 120 member organisations. Two participants informed the tier three group: those who were members of the African National Congress (ANC) and who had direct links with the CBM, playing a critical role in sanctioning its early and later roles. And, six participants informed the tier four group: those who operated outside the CBM, who knew about it but were not directly involved in it, and who were involved through other spheres with businesses' role in helping 
dismantle apartheid. They provided an important contextual, outside-looking-in perspective on the story and on the role of business in the change process and the prevailing conditions in the country at the time and over the course of the decade studied. For purposes of this article, the tier one participant data were used.

The research team consisted of three members: one a resident South African, one a USA resident South African, and the third, a USA scholar and internationally renowned expert in constructivist inquiry. Both South African members had extensive knowledge of and varying direct experience with the CBM. This insider-outsider membership of the research team helped to inform richer data collection, analysis and description of outcomes (Merriam, JohnsonBailey, Lee, Kee, Ntseane \& Muhamad, 2001). The constant comparison content analysis method was employed, together with extensive peer checking and rechecking, to inform the identification and synthesis of the resulting data themes (Lincoln \& Guba, 1985). Where possible, member checking of data themes was conducted. Initially 19 themes were identified and described. Through further analysis and peer checking these themes were reduced, first to 16 (Lynham et al., 2006), and finally to 12 . As a reminder, these 12 data themes apply to the first and inner group of study participants (nine in all), and are presented in abbreviated version in Table 2 following.

Although not consciously articulated in systems terms, nor indeed using the jargon contained in this paper, business in South Africa took a path of proactive engagement so as to contribute to fundamental system-wide change. There is little doubt that one of the objectives of business was to ensure an essentially dominant capitalist focus for the South African economy under a new government and a relatively smooth transition to a new order. But business also was deeply concerned to demonstrate its contribution to change and its will to lead that change. The style of engagement was akin to that of servant leadership but that, as this paper has already indicated, is but one instrumentalist view of how to understand leadership. More importantly, the business contribution was systemic and the leadership process was one of dialogue and response to emergence. There were no formal rules for engagement. There was no publicity, nor an identifiable leader nor followers. There was indeed an evolving, very complex and fragile situation and there were many actors, but the leadership resided in the process and the interaction within the system. Business leadership demonstrated a capacity to engage systems thinking as a framework for practice through seeing itself as part of a broader dynamic space that it could influence to change. Recognition of being integral to the system of political change and therefore being significant in defining the nature of the environment were prominent characteristics of the leadership practice of the period. Business leadership further showed a framework for understanding through its manner of engagement and a capacity to shift roles and accommodate perceptual changes as these emerged and as the environment changed in a fluid and indeterminate manner.

How the SA case study of business leadership is illustrative of leadership as a systemic phenomenon in terms of these two frameworks (practice, understanding and repsonsibility) is demonstrated, respectively, in a condensed comparative analysis of the twelve case study themes against each of these frameworks, presented in Tables 2 below. The twelve themes used to describe the lived experience of business leadership that is the focus of the case study are: 1) Acting as non-partisan conduits of political and national change; 2) Strictly adhering to explicitly agreed rules of conduct; 3 ) Enrolling a community of shared vision and values; 4) Listening deeply, in order to understand and empathize; 5) Creating space to think and act fundamentally differently; 6) Earning trust and the authority to act; 7) Building bridges through strategic conversations; 8) Leveraging the power of quiet leadership; 9) Taking immense risks and making personal sacrifices; 10) Leading change, and acting from a position of power; 11) Engaging in critique followed by committed action; and 12) Recognizing tipping point moments, and attending to and leveraging driving forces in the environment (see corresponding Table for further description).

\section{Conclusions}

The central argument of this paper was that there is a substantial and symbiotic relationship between the core tenets of systems thinking and those of leadership. Contemporary literature on the characteristics of leadership as an emergent, process-orientated phenomenon, serves to underscore the conceptual connections that are the proposition of this paper.

Although the above Table 2 contains a very synoptic version (in the last column) of the content of this paper, the abbreviated theme descriptions, in themselves, convey the sense of stewardship - and the processes for engaging in the cause of stewardship - that the business leaders displayed. From a leadership process perspective, the abbreviated theme descriptions contained in Table 2 are also descriptive of the ethos and approach of systems thinking in dealing with complex social phenomena. The expressed ideals of systems thinking as a framework for practical engagement, as a means of understanding complex relationships and the quest for responsible social stewardship and ethical practices are proposed to be the parallel ideals of leadership in the service of social stewardship.

It has been argued that stewardship embodies holistic and integrative thinking. Systems thinking and complexity theory define this. Leadership, too, can be viewed as an articulation of systems thinking. The actions of South African business in the period 1984-1994 (and as summarised In Table 2) have shown the potential that business possesses for meaningful socio-cultural stewardship in the context of change, and indeed the practices and understandings by which that leadership might occur. The anticipation is that the leadership expected from business, framed by a robust understanding of the "new language" of systems, and by leadership as a systemic process, can move society towards a condition of continuous improvement through dialogue and mutual learning. 
Table 2: The SA business case study as illustrations of a framework for practice/understanding/responsibility

\begin{tabular}{|c|c|c|}
\hline $\begin{array}{c}\text { Theme number } \\
\text { and name }\end{array}$ & Abbreviated theme descriptions & $\begin{array}{c}\text { Illustrations of a Framework for } \\
\text { practice/understanding/responsibility }\end{array}$ \\
\hline $\begin{array}{l}\text { 1. Acting as non- } \\
\text { partisan conduits of } \\
\text { political and } \\
\text { national change }\end{array}$ & $\begin{array}{l}\text { Demonstrating non-partisanship and consistently } \\
\text { acting in a non-partisan manner; Serving and acting as } \\
\text { shuttle diplomats, shuttling among various partisan } \\
\text { groups for the purpose of relationship building, } \\
\text { consensus seeking, negotiated agreement, and } \\
\text { movement towards shared commitment, action and } \\
\text { outcome. }\end{array}$ & $\begin{array}{l}\text { Practice: Active engagement of diverse } \\
\text { perspectives. } \\
\text { Understanding: Comprehending the dynamic } \\
\text { characteristics of systems and primary } \\
\text { significance of relationships. } \\
\text { Responsibility: Creating an open dialogue } \\
\text { space. }\end{array}$ \\
\hline $\begin{array}{l}\text { 2. Strictly adhering } \\
\text { to explicitly agreed } \\
\text { rules of conduct }\end{array}$ & $\begin{array}{l}\text { Consistently acting off strict rules of dialogue and } \\
\text { engagement-held and adhered to by all participating } \\
\text { business leaders in this movement; Having significant } \\
\text { consequences to ongoing participation if rules not } \\
\text { adhered to }\end{array}$ & $\begin{array}{l}\text { Practice: Respect for agreed processes for } \\
\text { engagement to avoid lapse into disorder and } \\
\text { system-wide collapse. } \\
\text { Understanding: Systems develop defined } \\
\text { processes that legitimise engagement within } \\
\text { and between them } \\
\text { Responsibility: Inviolate adherence to the } \\
\text { established and evolving rules for } \\
\text { engagement in the system. }\end{array}$ \\
\hline $\begin{array}{l}\text { 3. Enrolling a } \\
\text { community of } \\
\text { shared vision and } \\
\text { values }\end{array}$ & $\begin{array}{l}\text { Developing a shared vision of, and commitment to, a } \\
\text { democratic, free South Africa in which their } \\
\text { grandchildren, and their grandchildren's } \\
\text { grandchildren, could live, thrive and } \\
\text { prosper... socially, politically, culturally, and } \\
\text { economically; Pursuing a humane and socially, } \\
\text { politically, and economically just South Africa for all; } \\
\text { Believing that everyone is due respect and dignity; } \\
\text { Acting with great humility, not seeking rewards or } \\
\text { recognition for actions taken; Understanding that } \\
\text { business leadership has a responsibility beyond that of } \\
\text { business performance, to the greater good of the } \\
\text { environment, too }\end{array}$ & $\begin{array}{l}\text { Practice: Mobilisation of significant voices } \\
\text { around common value positions. } \\
\text { Understanding: Awareness of business as a } \\
\text { significant element in a broader systemic } \\
\text { environment. } \\
\text { Responsibility: An acceptance of stewardship } \\
\text { in the cause of social justice as the legitimate } \\
\text { business of business }\end{array}$ \\
\hline $\begin{array}{l}\text { 4. Listening deeply, } \\
\text { in order to } \\
\text { understand and } \\
\text { empathize }\end{array}$ & $\begin{array}{l}\text { Being willing to unzip one's skin and listen for deep } \\
\text { understanding; Often having to recognize one's own } \\
\text { lack of familiarity and comfort with diverse cultural } \\
\text { backgrounds, and listening through these blind spots } \\
\text { and moments of discomfort }\end{array}$ & $\begin{array}{l}\text { Practice: Active dialogue as a means towards } \\
\text { systemic effectiveness. } \\
\text { Understanding: Adoption of a "learning" } \\
\text { approach to complex issues and not to } \\
\text { assume immediacy of solution. } \\
\text { Responsibility: Listening to unfamiliar } \\
\text { voices and perspectives. }\end{array}$ \\
\hline $\begin{array}{l}\text { 5. Creating space to } \\
\text { think and act } \\
\text { fundamentally } \\
\text { differently }\end{array}$ & $\begin{array}{l}\text { Holding conversations in the cracks, in the in-between } \\
\text { spaces not on the immediate radar screen of } \\
\text { oppressive or opposing forces; Pioneering new } \\
\text { interactions, new ways of thinking and doing }\end{array}$ & $\begin{array}{l}\text { Practice: Being aware of the "spaces in } \\
\text { between" as representing opportunity for } \\
\text { quiet progress and renewed insights. } \\
\text { Understanding: The systemic value of } \\
\text { relationships. } \\
\text { Responsibility: Promoting a perspective } \\
\text { without subordinating those of others. }\end{array}$ \\
\hline $\begin{array}{l}\text { 6. Earning trust and } \\
\text { the authority to act }\end{array}$ & $\begin{array}{l}\text { Meeting with and being among the people-- } \\
\text { recognizing that conversations had to include all, and } \\
\text { having the patience and persistence to keep meeting } \\
\text { and keep talking until change began to happen; } \\
\text { Earning the right to stand up and act on behalf of- } \\
\text { earning and extending unquestionable trust, and the } \\
\text { authority to act, from all parties and players involved }\end{array}$ & $\begin{array}{l}\text { Practice: Being inclusive and allowing } \\
\text { change to be part of the "flow" in and } \\
\text { between participants in the system } \\
\text { Understanding: Realising that trust requires } \\
\text { patience and work and can undermine system } \\
\text { progress if abused. } \\
\text { Responsibility: Significance and value of } \\
\text { trust }\end{array}$ \\
\hline
\end{tabular}




\begin{tabular}{l|l|l}
\hline $\begin{array}{l}\text { 7. Building bridges } \\
\text { through strategic } \\
\text { conversations }\end{array}$ & $\begin{array}{l}\text { Holding consensus seeking, strategic conversations- } \\
\text { and persisting with these conversations through } \\
\text { diverse and opposed ideologies, until consensus could } \\
\text { be sought and reached; Understanding the importance } \\
\text { of ongoing communication to all parties, across all } \\
\text { perspectives }\end{array}$ & $\begin{array}{l}\text { Practice: Leadership is a systemic act that } \\
\text { emergent phenomenon accommodating } \\
\text { multiple perspectives leading to action. }\end{array}$
\end{tabular}

\begin{tabular}{|c|c|c|}
\hline & & $\begin{array}{l}\text { Responsibility: Not assuming knowledge that } \\
\text { is not mandated by the system. }\end{array}$ \\
\hline $\begin{array}{l}\text { 8. Leveraging the } \\
\text { power of quiet } \\
\text { leadership }\end{array}$ & $\begin{array}{l}\text { Through an agreed code of no personal or collective } \\
\text { acclaim, being able to step forward, backward or } \\
\text { aside, as needed, to successfully attend to the needs } \\
\text { and purpose of the moment; Never seeking } \\
\text { recognition or acknowledgement }\end{array}$ & $\begin{array}{l}\text { Practice: Not seeking individual recognition } \\
\text { Understanding:-Seeing leadership as a } \\
\text { collective process where leaders and } \\
\text { followers are seen as seamless parts of a } \\
\text { process that delivers leadership; that actors } \\
\text { are not confused with process. }\end{array}$ \\
\hline
\end{tabular}

Responsibility: Recognising the evolutionary nature of leadership that does not depend on individual power.

\begin{tabular}{llll}
\hline $\begin{array}{l}\text { 9. Taking immense } \\
\text { risks and making } \\
\text { personal sacrifices }\end{array}$ & $\begin{array}{l}\text { Taking substantial personal risk and making unusual } \\
\text { personal commitments of time, effort, energy, and } \\
\text { expertise - often at the sacrifice of family, other } \\
\text { personal, and internal company, obligations and } \\
\text { responsibilities; Having the courage to take stands } \\
\text { inside their businesses, too, stands that were risky to } \\
\text { their careers and businesses at the time }\end{array}$ & $\begin{array}{l}\text { Practice: Making sacrifices for the overall } \\
\text { of a system of social processes that are not } \\
\text { normally the "business of business" }\end{array}$
\end{tabular}
their careers and businesses at the time

10. Leading change,
and acting from a
position of power
position of power top executive active engagement and leadership involvement in the necessary change processes, and in so doing demonstrating a clear commitment to their businesses to socially conscious change and action; Having the courage to crash system boundaries and to so act across and outside of these boundaries; understanding the leverage potential of collective power
Stepping up, at the top-recognizing the importance of

Responsibility: Taking a stand on issues of principle that reflect the ethic of stewardship

Practice: Acting as part of a system of concern that transcends the immediate organisational system boundaries.

Understanding: Awareness of the significance of business as a part of the environment with enormous capacity to influence and shape the nature of the environment.

Responsibility: Being aware of business as a significant vehicle for social and environmental justice.

\begin{tabular}{|c|c|c|}
\hline $\begin{array}{l}\text { 11. Engaging in } \\
\text { critique followed by } \\
\text { committed action }\end{array}$ & $\begin{array}{l}\text { Engaging in action committed critique-being } \\
\text { prepared to act, often on behalf of, for better, shared } \\
\text { and agreed outcomes; Understanding that critique } \\
\text { needs to be followed by committed action }\end{array}$ & $\begin{array}{l}\text { Practice: Commitment to shared action } \\
\text { Understanding: That actions are followed by } \\
\text { reaction requiring openness to learning and } \\
\text { self-regulating adjustment. } \\
\text { Responsibility: Understanding that } \\
\text { leadership requires committed action to } \\
\text { shared beliefs. }\end{array}$ \\
\hline $\begin{array}{l}\text { 12. Recognizing } \\
\text { tipping point } \\
\text { moments, and } \\
\text { attending to and } \\
\text { leveraging driving } \\
\text { forces in the } \\
\text { environment }\end{array}$ & $\begin{array}{l}\text { Knowing that the environment provided a unique kind } \\
\text { of leverage to lead in different ways; Remaining } \\
\text { strategically focused, aware and engaged in the larger } \\
\text { national and international environments; responding } \\
\text { as, when and where required during numerous } \\
\text { nationally defining moments }\end{array}$ & $\begin{array}{l}\text { Practice: Acting strategically and } \\
\text { opportunistically. } \\
\text { Understanding: Developing a capacity to } \\
\text { stay informed and the value of information as } \\
\text { the catalyst for achieving system wide } \\
\text { progress. } \\
\text { Responsibility: Holding and enacting the } \\
\text { vision in an ethically responsible way. }\end{array}$ \\
\hline
\end{tabular}


The thoughts in this paper could perhaps be dismissed as the musings of idealists who hold out Utopian hope for business-led miracles that deliver social change through reformed leadership practices derived from systems thinking. Yet, it is from business itself that the concept of global stewardship derives and it is business that holds considerable capacity to influence value positions and practices in areas of social, political and environmental crisis. In itself, the recognition of business as a primary stabilising influence in post-conflict situations speaks to the potential that business has to influence and consolidate socio-political change. This is widely recognised and embodied in the usually mutually-engaging stance of business and government.

\section{Acknowledgement}

The authors gratefully acknowledge the interest and support of Vassi Naidoo, Director, Deloitte UK Global Management Partner-Talent, email: vassnaidoo@deloitte.co.uk who helped make the research into the processes of the Consultative Business Movement possible.

\section{References}

Alvesson, M. \& Deetz, S. 1996. 'Critical theory and postmodernism: Approaches to organisational studies'. In Clegg, R., Hardy, C. \& Nord, W.R. (Eds.) Handbook of organisational studies. London: Sage.

Banathy, B.H. 1996. Designing social systems in a changing world. New York and London: Plenum Press.

Bernstein, A. 2010. The case for business in developing economies. Johannesburg: Penguin Books.

Boyatzis, R. \& McKee, A. 2005. Resonant leadership. Boston: Harvard Business School Press.

Boulding, K. 1956. 'General systems theory: The skeleton of science', Management Science 2(3):197-208.

Burns, J.M. 1978. Leadership. New York: Harper and Row.

Cayer, M. 2005. 'The five dimensions of Bohm's dialogue'. In Banathy B. \& Jelink, P.M. (Eds.) Dialogue as a means of collective communication. New York: Kluwer Academic/Plenum Publishers.

Churchman, C.W. 1968. The systems approach. New York: Delta Books.

Cilliers, P. 2000. 'Rules and complex systems', Emergence 2(3): 40-50.

Cohen, N. \& Ben-Porat, N. 2008. 'Business communities and peace: The cost-benefit calculations of political involvement', Peace and Change, 33(3): 426-446.

Csikszentmihalyi, M. 2003. Good business: Leadership, flow and the making of meaning. London: Hodder and Stoughton.
De Pree, M. 1989. Leadership is an art. New York: Doubleday

Dervitsiotis, K.N. 2005. 'Creating conditions to nourish sustainable organizational excellence', Total Quality Management 16(8-9): 925-843.

Fiedler, F.E. 1967. A theory of leadership effectiveness. New York: McGraw-Hill.

Flood, R.L. \& Jackson, M.C. 1991. Creative problem solving. Chichester: Wiley.

Friedman, M. 1970. 'The social responsibility of business is to increase its profits', New York Times Magazine. 13 September.

Jackson, M.C. 2009. 'Fifty years of systems thinking for management', Journal of the Operational Research Society 60: $\mathrm{S} 24-\mathrm{S} 32$.

Kahane, A. 2004. Solving tough problems. San Francisco: Berret-Koehler Publishers.

Kurtz, C.F. \& Snowden, D.J. 2003. 'The new dynamics of strategy: Sense-making in a complex and complicated world', IBM Systems Journal 24(3): 462-483.

Laszlo, E. 2006. The chaos point: The world at the crossroads. London: Piatkus Books.

Lewin R. 1992. Complexity: Life at the edge of chaos. London: Macmillan.

Lincoln, Y. S. \& E. G. Guba 1985. Naturalistic inquiry. Beverly Hills, CA.: Sage.

Lincoln, Y. S. \& E. G. Guba 2005. 'Paradigmatic controversies, contradictions, and emerging confluences'. In Denzin, N.K. \& Lincoln, Y.S. (Eds.). The Sage handbook of qualitative research. $3^{\text {rd }}$ Edition. Thousand Oaks, CA: Sage Publishers.

Lincoln, Y. S., \& Lynham, S. A. 2011. 'Criteria for assessing theory in human resource development from an interpretive perspective', Human Resource Development International, 14(1): 3-22.

Lipton, M. 2007. 'The role of business under apartheid'. In Stolten, H.E. (Ed.). History making and present day politics. Uppsala: NordiskaAfrikainstitutet.

Lynham, S.A. 2000. The development of a theory of responsible leadership for performance. St.Paul, MN: Human Resource Development Research Center, University of Minnesota,

Lynham, S.A, Taylor, R.G., Naidoo, V. \& Dooley, L.M.. 2006. 'Corporate leadership for economic, social and political change: Principles and practices learned from South African business leaders', Journal of Business and Society, 19(1\&2): 172-186. 
Mbeki,T 2006. Nelson Mandela Memorial Lecture, University of the Witwatersrand, Johannesburg, 29 July.

Merriam, S.B., Johnson-Bailey, J., Lee, M., Kee, Y, Ntseane, G. \& Muhamad, M. 2001. 'Power and positionality: Negotiating insider/outsider status within and across cultures', Interntiojnal Journal of Lifelong Education 20(5): 405-416.

Mingers, J. 1997. 'Systems typologies in the light of autopoiesis: A reconceptualization of Boulding's hierarchy, and a typology of self-referential systems', Systems Research and Behavioural Science 14: 303-313.

Morgan, G. 1986. Images of organization. Beverley Hills CA: Sage.

Pierce, B.D. \& White, R. 1999. 'The evolution of social structure: Why biology matters', Academy of Management Review 24(4): 843-853.

Reynolds, M.D. 2008. 'Getting a grip: A critical systems framework for corporate responsibility', Systems Research and Behavioural Science 25: 383-395.

Senge, P., Kleiner, A., Roberts, C., Ross, R., Roth, G. \& Smith, B. 1999. The dance of change. London: Nicholas Brealey Publishing.

Taylor, R.G. 2004. 'Leading in uncertain times'. In Meyer, T.N.A. \& Bonelli, I. Conversations in leadership: South African perspectives. Gauteng: Knowres Publishing.

Terreblanche, S. 2002. A history of inequality in South Africa: 1652-2002. Pietermaritzburg: University of Natal Press.

Van Vugt, M. 2006. 'Evolutionary origins of leadership and followership', Personality and Social Psychology Review 10(4): 354-371.

Von Bertallanfy, L. 1968. General systems theory. Harmondsworth: Penguin.

Van Manen, M. 1990. Researching lived experience: Human science for an action sensitive pedagogy. University of Western Ontario, Canada: Althouse Press.

Wilson, E.O. 1998. Consilience. London: Abacus.

World Economic Forum (WEF). 2004. South Africa at 10: Perspectives by political, business and civil leaders. Cape Town: Human \& Rousseau.

Wood, M. 2005. 'The fallacy of misplaced leadership', Journal of Management Studies 42(6): 1101-1121.

Zohar, D. \& Marshall, I. 1994. The quantum society. London: Flamingo. 